\title{
Restriction endonuclease digest patterns of chromosomal DNA from group $B$-haemolytic streptococci
}

\author{
YUKIKO NAGANO, N. NAGANO*, S. TAKAHASHI†§, K. MURONO $\ddagger$, K. FUJITA $\ddagger$, F. TAGUCHI \\ and Y. OKUWAKIt
}

Department of Microbiology, School of Hygienic Sciences, Kitasato University, 1-15-1 Kitasato, Sagamihara, *Medical Microbiology Laboratory, Funabashi Medical Center, 1-21-1 Kanasugi, Funabashi, +Department of Microbiology, Joshi-Eiyoh University, 3-9-21 Chiyoda, Sakado, and $\ddagger$ Department of Pediatrics, Asahikawa Medical College, 4-5-311 Nishikagura, Asahikawa, Japan

\begin{abstract}
Summary. Scanning densitometry and computer-assisted numerical analysis were used to examine restriction endonuclease digest patterns (RDPs) of chromosomal DNA from 26 infecting strains and 44 vaginal isolates of group B $\beta$-haemolytic streptococci (GBS). At the 95\% similarity level, HindIII RDPs of serotype Ia and III strains clustered into four and three RDP types, respectively. Nine of 10 strains from neonates with early-onset septicaemia belonged to two particular RDP types (Ia-3 and III-3). In contrast, serotype III GBS strains from meningitis cases were not characterised by particular RDP types. Associations between RDPs and certain phenotypic characteristics were also found.
\end{abstract}

\section{Introduction}

Group B $\beta$-haemolytic streptococci (GBS) are associated with various infections of man, particularly in the neonatal period. Type-specific capsular polysaccharide antigens allow GBS to be classified into serotypes Ia, Ib, II, III, IV and V, and a candidate serotype NT6. ${ }^{1-3}$ These serotypes may be further classified according to the presence of protein antigens c, R or X. ${ }^{4,5}$ Epidemiological studies of the serotype distribution of infecting GBS isolates show that more than half the strains from meningitis belong to serotype III, ${ }^{6,7}$ whereas the majority of cases of septicaemia with lower respiratory tract infection are caused by strains of serotype Ia. ${ }^{8-10}$ However, it is still unclear whether GBS strains of serotypes III and Ia isolated from infected infants belong to a specific subgroup within these serotypes.

Restriction endonuclease digest pattern (RDP) analysis of chromosomal DNA has been used successfully to characterise strains of various bacteria,${ }^{11}$ particularly for epidemiological typing, when other conventional methods cannot be used.

To improve the technique and increase objectivity, electrophoresis gels may be scanned by a densitometer ${ }^{12}$ and the patterns analysed by computerassisted numerical analysis. ${ }^{13}$ In the present study this approach was employed to compare GBS strains from infants with group B streptococcal infections with vaginal isolates from healthy women. The aim was to clarify whether infecting GBS isolates of serotypes III and Ia were characterised by a particular RDP.

Received 20 July 1990; accepted 11 Dec. 1990

$\S$ Correspondence should be sent to Dr S. Takahashi.

\section{Materials and methods}

\section{Bacterial strains}

GBS strains, comprising 26 isolates from infected infants and 44 vaginal isolates from unrelated healthy women, are listed in table I. Organisms were stored at $-80^{\circ} \mathrm{C}$ until use, as described previously. ${ }^{14}$

\section{Serotyping}

All strains were grouped serologically by the Phadirect streptococcus method (Pharmacia Diagnostics, Uppsala, Sweden). Serotyping was performed by the capillary precipitin method with antisera (Denka Seiken, Tokyo, Japan) to the polysaccharide antigens of types Ia, Ib, II, III, IV, V and NT6, and to the protein antigens $\mathrm{c}, \mathrm{R}$ and $\mathrm{X}$, according to the manufacturer's instructions.

\section{Preparation of DNA}

Bacteria grown in $20 \mathrm{ml}$ of Todd-Hewitt Broth (BBL, Microbiology Systems Cockeysville, MD, USA) to late-exponential growth phase $\left(\mathrm{OD}_{600}, 0.6\right)$ were pelleted and washed with $4 \mathrm{ml}$ Tris-EDTA $(40 \mathrm{~mm}$ Tris-50 mM disodium edetate, $\mathrm{pH}$ 6.8). Cells were resuspended in $2 \mathrm{ml}$ of mutanolysin (Sigma) solution $\left(100 \mathrm{U} / \mathrm{ml}\right.$ of Tris-EDTA) and incubated at $37^{\circ} \mathrm{C}$ until the suspension became translucent $(1 \cdot 5-2 \mathrm{~h})$. Following the addition of $2 \mathrm{ml}$ of lysing solution (sodium dodecyl sulphate $2 \%$ in Tris-EDTA), the mixture was allowed to stand at room temperature for $5 \mathrm{~min}$. Salt precipitation was induced by adding $2 \mathrm{ml}$ chilled $\left(4^{\circ} \mathrm{C}\right)$ $3 \mathrm{~m}$ sodium acetate-acetic acid ( $\mathrm{pH} 5.5)$ to the lysate 
Table I. Sources and characters of GBS strains

\begin{tabular}{|c|c|c|c|c|c|c|}
\hline $\begin{array}{l}\text { Strain } \\
\text { no. }\end{array}$ & Source & Serotype & $\begin{array}{l}\text { RDP } \\
\text { type }\end{array}$ & $\begin{array}{c}\text { SA } \\
\text { content }\end{array}$ & $\begin{array}{c}\text { Tc } \\
\text { susceptibility }\end{array}$ & $\begin{array}{l}\text { Growth } \\
\text { kinetics* }\end{array}$ \\
\hline 1 & V & $\mathrm{Ia} / \mathrm{c}$ & Ia-1 & L & $\mathbf{S}$ & - \\
\hline 2 & V & Ia & Ia-1 & $\mathbf{L}$ & $\mathbf{S}$ & - \\
\hline 3 & V & $\mathrm{Ia} / \mathrm{c}$ & $\mathrm{Ia}-1$ & $\mathbf{L}$ & $\mathbf{S}$ & - \\
\hline 4 & V & Ia & $\mathrm{Ia}-1$ & $\mathbf{L}$ & $S$ & - \\
\hline 5 & B & $\mathrm{Ia} / \mathrm{c}$ & $\mathrm{Ia}-2$ & $\mathbf{H}$ & $\mathbf{R}$ & - \\
\hline 6 & CSF & $\mathrm{Ia} / \mathrm{c}$ & $\mathrm{Ia}-2$ & $\mathbf{H}$ & $\mathbf{R}$ & - \\
\hline 7 & V & $\mathrm{Ia} / \mathrm{c}$ & $\mathrm{Ia}-2$ & $\mathbf{M}$ & $\mathbf{R}$ & - \\
\hline 8 & V & $\mathrm{Ia} / \mathrm{c}$ & $\mathrm{Ia}-2$ & H & $\mathbf{R}$ & - \\
\hline 9 & V & $\mathrm{Ia} / \mathrm{c}$ & $\mathrm{Ia}-2$ & $\mathbf{L}$ & $\mathbf{R}$ & - \\
\hline 10 & V & $\mathrm{Ia} / \mathrm{c}$ & Ia-2 & $\mathbf{M}$ & $\mathbf{R}$ & - \\
\hline 11 & B & Ia & $\mathrm{Ia}-3$ & $\mathbf{H}$ & $\mathbf{S}$ & - \\
\hline 12 & B & $\mathrm{Ia} / \mathrm{c}$ & $\mathrm{Ia}-3$ & $\mathrm{~L}$ & $\mathbf{S}$ & - \\
\hline 13 & B & $\mathrm{Ia} / \mathrm{c}$ & $\mathrm{Ia}-3$ & $\mathrm{H}$ & $\mathbf{R}$ & - \\
\hline 14 & B & $\mathrm{Ia} / \mathrm{c}$ & $\mathrm{Ia}-3$ & $\mathrm{H}$ & $\mathbf{R}$ & - \\
\hline 15 & B & $\mathrm{Ia} / \mathrm{c}$ & Ia-3 & $\mathrm{H}$ & $\mathbf{R}$ & - \\
\hline 16 & V & $\mathrm{Ia} / \mathrm{c}$ & $\mathrm{Ia}-3$ & $\mathrm{H}$ & $\mathbf{S}$ & - \\
\hline 17 & V & $\mathrm{Ia} / \mathrm{c}$ & $\mathrm{Ia}-3$ & L & $\mathbf{S}$ & - \\
\hline 18 & V & Ia & $\mathrm{Ia}-3$ & $\mathbf{M}$ & $\mathbf{S}$ & - \\
\hline 19 & CSF & Ia & $\mathrm{Ia}-4$ & $\mathbf{L}$ & $\mathbf{R}$ & - \\
\hline 20 & CSF & Ia & $\mathrm{Ia}-4$ & $\mathrm{~L}$ & $\mathbf{R}$ & - \\
\hline 21 & V & Ia & Ia-4 & $\mathbf{M}$ & $\mathbf{R}$ & - \\
\hline 22 & CSF & III & III-1 & L & $\mathrm{S}$ & - \\
\hline 23 & V & III & III-1 & $\mathbf{L}$ & $\mathbf{S}$ & - \\
\hline 24 & V & III & III-1 & $\mathrm{L}$ & $S$ & - \\
\hline 25 & V & III & III-1 & $\mathbf{L}$ & $\mathbf{S}$ & - \\
\hline 26 & V & III & III-1 & $\mathrm{L}$ & $S$ & - \\
\hline 27 & V & III & III-1 & L & $\mathbf{S}$ & - \\
\hline 28 & CSF & III/R & III-2 & $\mathbf{L}$ & $\mathbf{R}$ & - \\
\hline 29 & B & III/R & III-2 & $\mathbf{L}$ & $\mathbf{R}$ & - \\
\hline 30 & CSF & III/R & III-2 & $\mathbf{L}$ & $\mathbf{R}$ & - \\
\hline 31 & CSF & III/R & III-2 & $\mathbf{L}$ & $\mathbf{R}$ & - \\
\hline 32 & B & III/R & III-2 & $\mathrm{L}$ & $\mathbf{R}$ & - \\
\hline 33 & B & III/R & III-2 & $\mathbf{L}$ & $\mathbf{R}$ & - \\
\hline 34 & B & III/R & III-2 & L & $\mathbf{R}$ & - \\
\hline 35 & CSF & III/R & III-2 & L & $\mathbf{R}$ & - \\
\hline 36 & CSF & III/R & III-2 & $\mathbf{L}$ & $\mathbf{R}$ & - \\
\hline 37 & V & III & III-2 & $\mathrm{H}$ & $\mathbf{R}$ & - \\
\hline 38 & V & III/R & III-2 & L & $\mathbf{R}$ & - \\
\hline 39 & V & III/R & III-2 & L & $\mathbf{R}$ & - \\
\hline 40 & V & III/R & III-2 & $\mathrm{L}$ & $\mathbf{R}$ & - \\
\hline 41 & B & III/R & III-3 & $\mathbf{M}$ & $\mathbf{R}$ & + \\
\hline 42 & B & III/R & III-3 & $\mathbf{M}$ & $\mathbf{R}$ & + \\
\hline 43 & $\mathrm{CSF}$ & III $/ \mathbf{R}$ & III-3 & $\mathbf{L}$ & $\mathbf{S}$ & + \\
\hline 44 & CSF & III/R & III-3 & $\mathbf{M}$ & $\mathbf{R}$ & + \\
\hline 45 & CSF & III/R & III-3 & $\mathbf{M}$ & $\mathbf{R}$ & + \\
\hline 46 & B & III/R & III-3 & $\mathbf{M}$ & $\mathbf{R}$ & + \\
\hline 47 & B & III/R & III-3 & $\mathrm{L}$ & $\mathbf{R}$ & + \\
\hline 48 & V & III/R & III-3 & $\mathrm{L}$ & $\mathbf{R}$ & + \\
\hline 49 & V & III/R & III-3 & $\mathbf{M}$ & $\mathbf{R}$ & + \\
\hline 50 & V & III/R & III-3 & L & $\mathbf{R}$ & + \\
\hline 51 & V & $\mathrm{Ib} / \mathrm{c}$ & $\mathrm{Ib}-1$ & $\mathbf{M}$ & $\mathbf{R}$ & - \\
\hline 52 & V & $\mathrm{Ib} / \mathrm{c}$ & Ib-1 & $\mathbf{L}$ & $\mathbf{S}$ & - \\
\hline 53 & V & $\mathrm{Ib} / \mathrm{c}$ & Ib-1 & $\mathrm{L}$ & S & - \\
\hline 54 & V & $\mathrm{Ib} / \mathrm{c}$ & Ib-1 & $\mathrm{L}$ & $\mathbf{S}$ & - \\
\hline 55 & V & $\mathrm{Ib} / \mathrm{c}$ & Ib-1 & $\mathbf{L}$ & $\mathbf{S}$ & - \\
\hline 56 & V & II/R & II-1 & L & $\mathbf{S}$ & - \\
\hline 57 & V & II/R & II-1 & $\mathbf{L}$ & $\mathbf{R}$ & - \\
\hline 58 & V & II $/ \mathbf{R}$ & II-1 & $\mathrm{L}$ & $\mathbf{R}$ & - \\
\hline 59 & V & II/R & II-1 & $\mathrm{L}$ & $\mathbf{R}$ & - \\
\hline 60 & V & II/R & $\mathrm{II}-2$ & L & $\mathbf{R}$ & - \\
\hline 61 & V & $\mathbf{V} / \mathbf{R}$ & V-1 & $\mathbf{L}$ & $\mathbf{R}$ & - \\
\hline 62 & V & $\mathbf{V} / \mathbf{R}$ & V-1 & $\mathbf{L}$ & $\mathbf{R}$ & - \\
\hline 63 & V & V & V-2 & $\mathrm{L}$ & $\mathbf{R}$ & - \\
\hline 64 & V & V & $\mathrm{V}-2$ & $\mathrm{~L}$ & $\mathbf{R}$ & - \\
\hline 65 & V & V & $\mathrm{V}-2$ & $\mathrm{~L}$ & $\mathbf{R}$ & - \\
\hline 66 & V & NT6/c & NT6-1 & $\bar{L}$ & $S$ & - \\
\hline 67 & V & NT6 & NT6-1 & $\mathbf{L}$ & $\mathbf{S}$ & - \\
\hline 68 & V & NT6/c & NT6-1 & $\mathrm{L}$ & $\mathbf{S}$ & - \\
\hline 69 & V & NT6 & NT6-1 & $\mathbf{L}$ & $\mathbf{S}$ & - \\
\hline 70 & V & NT6 & NT6-1 & $\mathbf{L}$ & $\mathbf{S}$ & - \\
\hline
\end{tabular}

V, vagina; B, blood; CSF, cerebrospinal fluid; SA, sialic acid; L, low; M, moderate; H, high; Tc, tetracycline; $S$, susceptible; $R$, resistant.

* Growth kinetics in FMC-200P medium; +, lag time growth; -, normal growth. 
and the material was centrifuged at $2100 \mathrm{~g}$ at $4^{\circ} \mathrm{C}$ for $1 \mathrm{~h}$. The supernate was treated with an equal volume of phenol-chloroform ( $v: v, 1: 1)$ and two volumes of chilled $\left(-20^{\circ} \mathrm{C}\right)$ ethanol $95 \%$ was added to the mixture. After standing at $-20^{\circ} \mathrm{C}$ for $1 \mathrm{~h}$, extracted DNA was pelleted by centrifugation at $2100 \mathrm{~g}$ at $4^{\circ} \mathrm{C}$ for $10 \mathrm{~min}$, and resuspended in $200 \mu \mathrm{l}$ Tris-acetic acid-EDTA (10 $\mathrm{mm}$ Tris acetic acid- $2 \mathrm{~mm}$ disodium edetate, pH 8.0). RNAase A ( $2 \mu \mathrm{l}, 1 \mathrm{mg} / \mathrm{ml})$ was added to the DNA sample and the reaction mixture was held at $0^{\circ} \mathrm{C}$ for $30 \mathrm{~min}$. After purification by treatment twice with phenol and chloroform, ${ }^{12}$ the DNA sample was mixed with $50 \mu \mathrm{l} 1 \mathrm{M}$ sodium acetate and DNA was precipitated with ethanol $95 \%$ and centrifuged, as described above. The DNA pellet was washed with chilled ethanol $70 \%$, dried under nitrogen and then dissolved in $20 \mu \mathrm{l}$ of Tris-acetic acid-EDTA and stored at $4^{\circ} \mathrm{C}$ until use.

\section{Detection of plasmid DNA}

Chromosomal DNA was denatured by adding $50 \mu 1$ alkaline solution (equal volumes of $100 \mathrm{~mm}$ Tris- $2 \mathrm{mM}$ disodium edetate and $0.2 \mathrm{~N} \mathrm{NaOH}$ ) to $2 \mu \mathrm{l}$ of DNA extract. After neutralisation with $25 \mu \mathrm{l} 3 \mathrm{M}$ sodium acetate-acetic acid ( $\mathrm{pH} 5.5$ ), ethanol precipitation and drying under nitrogen (as described above) the material was dissolved in $10 \mu \mathrm{l}$ of sterile water. Plasmid DNA was detected by electrophoresis as previously described. ${ }^{12}$

\section{Restriction endonuclease digestion}

The extracted DNA was treated with each of five endonucleases, BamHI, BgIII, HindIII, KpnI, and SalI (Takara Shuzo Co., Kyoto, Japan), under the conditions specified by the manufacturer. The reaction mixture (total volume $100 \mu \mathrm{l}$ ), containing $10 \mu \mathrm{l}$ of DNA solution and $100 \mathrm{U}$ of endonuclease, was allowed to react for $4 \mathrm{~h}$. After the addition of $25 \mu \mathrm{l}$ of $1 \mathrm{M}$ sodium acetate, digested DNA was precipitated in ethanol as described above and dissolved in $20 \mu \mathrm{l}$ of sterile water. Phage $\lambda$ DNA $(4 \mu \mathrm{g} / \mathrm{ml})$ was digested with HindIII, and used as the migration distance standard.

\section{Agarose gel electrophoresis}

The electrophoretic technique for densitometric scanning ${ }^{12}$ was used for the separation of digested DNA samples. Electrophoresis was performed in agarose gel $1.0 \%$ at $9.2 \mathrm{~V} / \mathrm{cm}(120 \mathrm{~V} / \mathrm{gel})$ for $6 \mathrm{~h}$. Gels were stained with ethidium bromide and photographed on a shortwave transilluminator (type TS36; Ultra-Violet Products Inc., San Gabriel, USA).

\section{Densitometric scanning and numerical analysis}

Densitometric scanning was performed as previously described, ${ }^{12}$ and numerical analysis was done by the method of Kersters and De Ley, ${ }^{13}$ except that the OD value of the area outside the sample lanes on the film was removed as background. Electrophoretograms on negative film were scanned with a scanning densitometer (Cliniscan, Helena Laboratories, Beaumont, USA) at $610 \mathrm{~nm}$ with a slit size of $2.5 \times 0.1 \mathrm{~mm}$. $O D$ values at regular intervals along the direction of migration, (72 measurement points $/ 10 \mathrm{~mm}$ of gel length) were recorded on a magnetic disk. Phage $\lambda$ DNA-HindIII digests-mol. wts $\left(10^{6}\right) 15 \cdot 27,6 \cdot 21$, 4.33 and 2.88-run on adjacent lanes were used as markers to correct for distortion of migration distance on the scanning pattern. One of the densitometric patterns of the phage $\lambda$ DNA-HindIII digests was designated as the reference pattern. Correction of the migration distance of the pattern (expansion or compression) to that of the reference pattern was done for each strain within each segment defined by the markers of the next lane. Similarity was calculated over a mol. wt range of $(15 \cdot 27-2 \cdot 88) \times 10^{6}$ comprising 218 measurement points; this excluded the low mol. wt regions containing low-intensity bands. The Pearson product moment correlation coefficients between all possible pairs of scanning corrected patterns were calculated on the basis of the OD value of the overlapping portion between a pair of the patterns, and similarity was expressed as a percentage value (multiplied by 100) for convenience. Patterns were clustered by the method of unweighted pair group average linkage (UPGMA). ${ }^{15}$ Data handling and analysis were performed with the aid of a locally written software package.

\section{Quantitation of sialic acid}

Cell-wall sialic acid (SA) was extracted from freezedried bacterial cells by acid-heat treatment as described previously. ${ }^{14} \mathrm{SA}$ was determined by the thiobarbituric acid method ${ }^{16}$ with $\mathrm{N}$-acetylneuraminic acid as the standard. According to previously described criteria ${ }^{14} \mathrm{SA}$ levels were classified as low ( $<9 \mu \mathrm{g} / \mathrm{mg}$ bacterial cell dry weight), moderate (9$12 \mu \mathrm{g} / \mathrm{mg})$, and high ( $>12 \mu \mathrm{g} / \mathrm{mg})$.

\section{Determination of MIC of tetracycline}

The MIC of tetracycline (Tc) against GBS isolates was determined by the microdilution broth method ${ }^{17}$ with an inoculum of $10^{6} \mathrm{cfu} / \mathrm{ml}$ in Mueller-Hinton Broth (BBL). Staphylococcus aureus ATCC 29213, Enterococcus faecalis ATCC 29212, Escherichia coli ATCC 25922 and Pseudomonas aeruginosa ATCC 27853 were used as controls. GBS strains with MICs $<1 \mu \mathrm{g} / \mathrm{ml}$ were classified as susceptible and strains with MICs $>8 \mu \mathrm{g} / \mathrm{ml}$ as resistant. ${ }^{18}$

\section{Growth kinetics in phosphate-containing media}

The method of Maurer and Mattingly, ${ }^{19}$ with a chemically defined medium ${ }^{20}$ containing $200 \mathrm{~mm}$ 
phosphate (FMC 200P medium), was followed. Growth kinetics were measured by recording absorbance with a spectrophotometer (Ultraspec Plus 4054, Pharmacia LKB Biochrom, Cambridge) at a $675 \mathrm{~nm}$. According to previously described criteria, isolates were classified as strains exhibiting lag time or normal growth kinetics. ${ }^{14}$

\section{Results}

\section{Plasmid DNA}

Plasmid DNA was not detected in alkali-denatured extracts of any of the $70 \mathrm{GBS}$ strains tested.

\section{Selection of restriction endonucleases}

To select appropriate enzymes for RDP analysis, preliminary experiments were performed with five restriction endonucleases on DNA from four GBS strains (strains 5, 6, 44 and 45). RDPs produced by $B a m H I, B g l \mathrm{II}, K p n I$ and $S a l \mathrm{I}$, were characterised by a broad band with segments of different sizes in the high mol. wt region. Such segments separate poorly with ordinary agarose gel electrophoretic techniques and these four enzymes were not used for further analysis. In contrast, RDPs produced by HindIII consisted of lower mol. wt segments $\left(<13 \times 10^{6}\right)$ and HindIII was adopted for the main study.

\section{Reproducibility of densitometric patterns}

To check the reproducibility of RDPs, electrophoresis was performed on three different gels with DNA from GBS strains 5, 6, 44 and 45, and similarities were calculated for each strain. The RDPs were highly reproducible between gels; average similarities for GBS strains 5, 6, 44 and 45 were $98 \cdot 8$ SD 0.4, 99.1 SD $0.5,98 \cdot 7$ SD 0.4 and 98.8 SD $0 \cdot 5$, respectively.

\section{Numerical analysis}

Agarose gel electrophoretograms of $\mathrm{HindIII}$ digests of DNA from representative GBS strains are shown in fig. 1. Numerical analysis results of HindIII RDPs, based on the determinations of similarity and UPGMA clustering, are summarised in fig. 2. Comparison at the $95 \%$ similarity level, where strains of different serotypes remained unclustered, revealed a total of 13 phenons, which were designated as RDP types. The average similarity of densitometric patterns within each of the RDP types Ia-1, Ib-1, II-1, V-1, V-2 and NT6-1 was $>98 \%$. For RDP types Ia-2, Ia3 , Ia-4, III-1, III-2, and III-3, the average similarity level of the densitometric patterns within each of the RDP types was $>96 \%$ but $<98 \%$, and the patterns in the low-mol. wt region were visually identical within each of the RDP types.

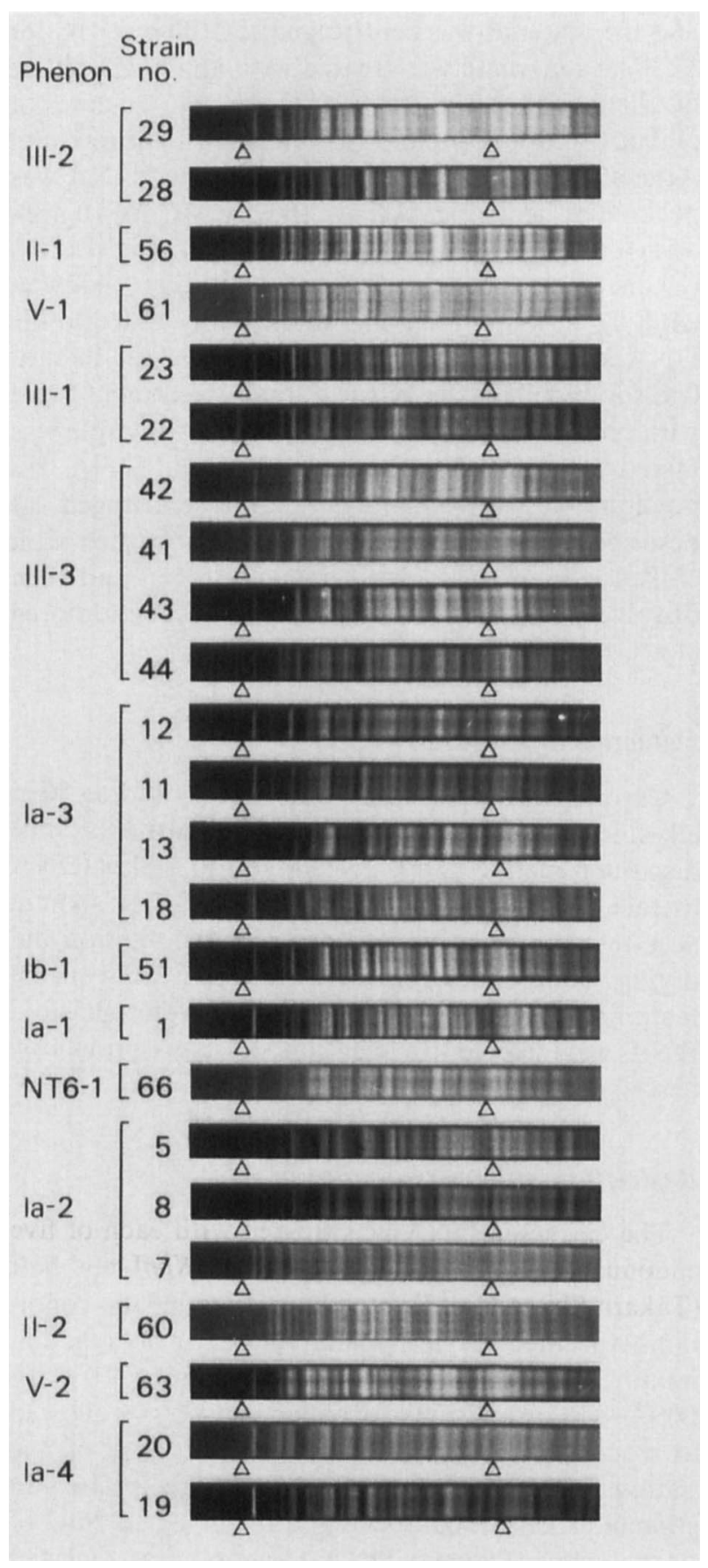

Fig. 1. Agarose gel electrophoretogram of HindIII digests of representative GBS strains. Migration distances of mol. wt standards $15.27 \times 10^{6}$ (left hand triangle) and $2.88 \times 10^{6}$ (right hand triangle) were used to correct patterns before calculations of similarity.

\section{RDP types and phenotypic characteristics}

RDP types, SA cell wall content, susceptibility to tetracycline, and growth kinetics in FMC 200P medium of serotype Ia and III GBS strains are shown in table II. The correlation of RDP type with each of these phenotypic characteristics was poor except that RDP types Ia-1 and III-1 consisted exclusively of strains that had low cell-wall SA levels and were tetracycline-susceptible and all strains of RDP type 


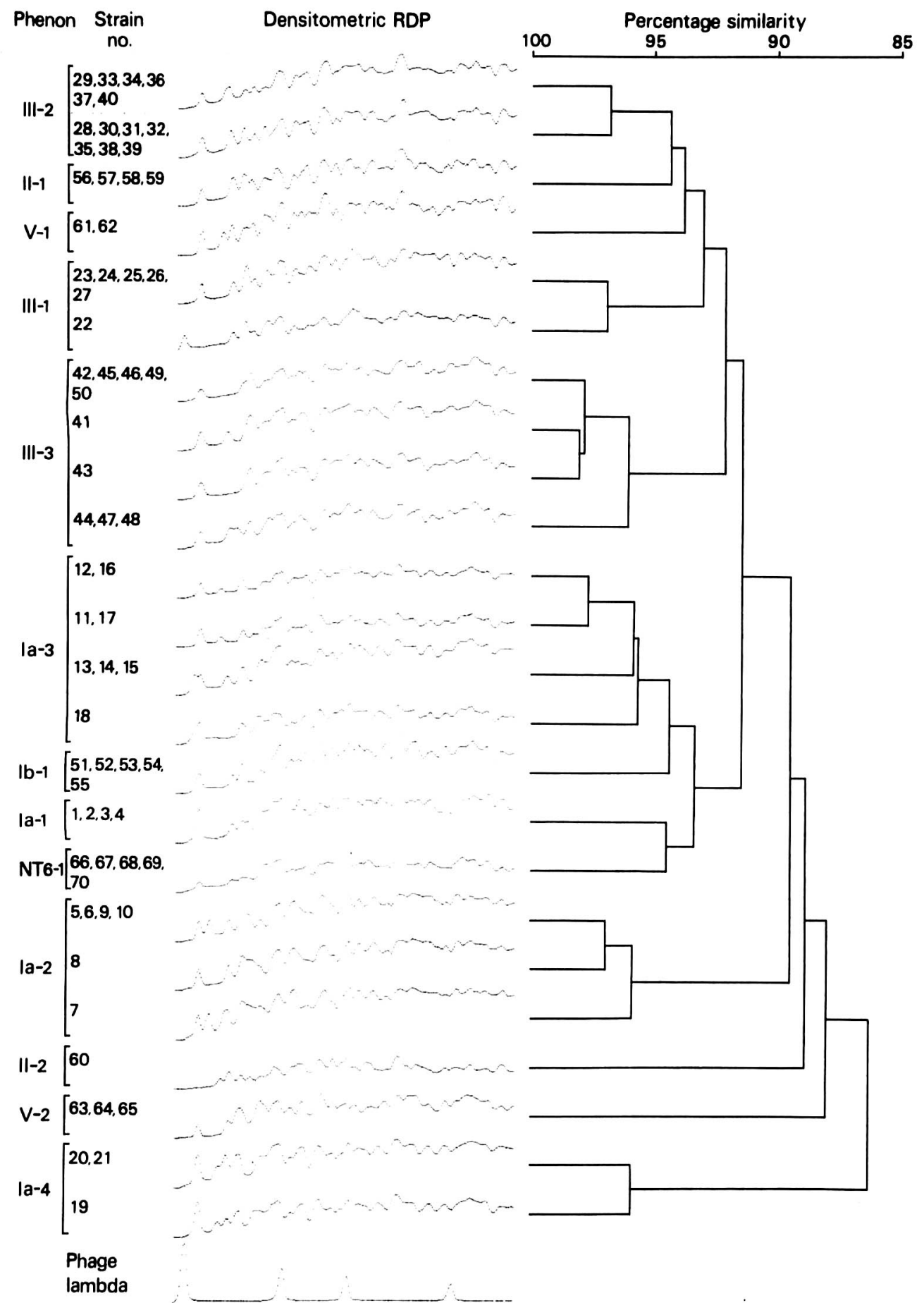

Fig. 2. Dendrogram of cluster analysis based on HindIII RDPs. Percentage similarities were determined by the correlation coefficient $(x$ $100)$ and UPGMA clustering. The densitometric RDP of a phage $\lambda$ DNA-HindIII digest mol. wt $\left(1.5 .27 \times 10^{6}, 6.21 \times 10^{6}, 4.33 \times 10^{6}\right.$ and $2.88 \times 10^{6}$, left to right) is shown at the bottom of the figure. Only representative (similarity $>98 \%$ ) corrected densitometric RDPs are shown. Phenons (RDP types) were formed at the $95 \%$ similarity level.

III-3 were unique in exhibiting lag time growth kinetics in FMC 200P medium.

\section{RDP types and GBS disease patterns}

For each of the 26 infecting isolates, RDP type and clinical disease classification were compared (table III). In cases of septicaemia occurring in the first 5 days of life, of 10 isolates, five were RDP type Ia-3, and four belonged to RDP type III-3. Isolates derived from meningitis did not belong to any particular RDP type.

\section{Discussion}

RDPs of chromosomal DNA between strains may vary in only a few fragments and the methods used in this study may not have detected such differences, particularly among the minor bands. Despite this, 
Table II. Phenotypic characters and RDP types of serotype Ia and III GBS strains

\begin{tabular}{|c|c|c|c|c|c|c|c|c|}
\hline \multirow{3}{*}{$\begin{array}{l}\text { RDP } \\
\text { type }\end{array}$} & \multicolumn{8}{|c|}{ Number of strains } \\
\hline & \multirow{2}{*}{ Total } & \multirow{2}{*}{ Inf } & \multirow{2}{*}{ col } & \multicolumn{3}{|c|}{ SA content } & \multirow{2}{*}{$\begin{array}{c}\text { Tc } \\
\text { susceptible }\end{array}$} & \multirow{2}{*}{$\begin{array}{l}\text { Lag time* } \\
\text { growth }\end{array}$} \\
\hline & & & & $\mathrm{H}$ & $\mathbf{M}$ & $\mathbf{L}$ & & \\
\hline Ia-1 & 4 & 0 & 4 & 0 & 0 & 4 & 4 & 0 \\
\hline $\mathrm{Ia}-2$ & 6 & 2 & 4 & 3 & 2 & 1 & 0 & 0 \\
\hline Ia-3 & 8 & 5 & 3 & 5 & 1 & 2 & 5 & 0 \\
\hline $\mathrm{Ia}-4$ & 3 & 2 & 1 & 0 & 1 & 2 & 0 & 0 \\
\hline III-1 & 6 & 1 & 5 & 0 & 0 & 6 & 6 & 0 \\
\hline III-2 & 13 & 9 & 4 & 1 & 0 & 12 & 0 & 0 \\
\hline III-3 & 10 & 7 & 3 & 0 & 6 & 4 & 1 & 10 \\
\hline
\end{tabular}

Inf, infecting isolates; col, colonising isolates; $\mathrm{SA}$, sialic acid; $\mathrm{H}$, high; $\mathrm{M}$, moderate $\mathrm{L}$, low ;

* In FMC-200P medium.

Table III. Disease pattern and RDP type of 26 GBS infecting isolates

\begin{tabular}{|c|c|c|c|c|}
\hline \multirow{2}{*}{$\begin{array}{c}\text { Strain } \\
\text { no. }\end{array}$} & \multirow{2}{*}{$\begin{array}{l}\text { RDP } \\
\text { type }\end{array}$} & \multirow{2}{*}{$\begin{array}{c}\text { Age of* } \\
\text { patient } \\
\text { (days) }\end{array}$} & \multicolumn{2}{|c|}{ Disease pattern } \\
\hline & & & Septicaemia & meningitis \\
\hline 11 & $\mathrm{Ia}-3$ & 0 & + & - \\
\hline 12 & $\mathrm{Ia}-3$ & 0 & + & - \\
\hline 14 & $\mathrm{Ia}-3$ & 2 & + & - \\
\hline 13 & $\mathrm{Ia}-3$ & 3 & + & - \\
\hline 15 & $\mathrm{Ia}-3$ & 3 & + & - \\
\hline 5 & $\mathrm{Ia}-2$ & 5 & - & + \\
\hline 6 & $\mathrm{Ia}-2$ & 8 & - & + \\
\hline 19 & $\mathrm{Ia}-4$ & 23 & - & + \\
\hline 20 & $\mathrm{Ia}-4$ & 48 & - & + \\
\hline 42 & III-3 & 0 & + & - \\
\hline 46 & III-3 & 0 & + & - \\
\hline 32 & III-2 & 1 & + & + \\
\hline 41 & III-3 & 3 & + & - \\
\hline 47 & III-3 & 3 & + & - \\
\hline 22 & III-1 & 3 & - & + \\
\hline 44 & III-3 & 7 & + & + \\
\hline 29 & III-2 & 9 & + & + \\
\hline 43 & III-3 & 16 & - & + \\
\hline 28 & III-2 & 17 & - & + \\
\hline 45 & III-3 & 19 & - & + \\
\hline 34 & III-2 & 22 & - & + \\
\hline 35 & III-2 & 24 & - & + \\
\hline 36 & III-2 & 38 & - & + \\
\hline 30 & III-2 & 37 & - & + \\
\hline 33 & III-2 & 71 & - & + \\
\hline 31 & III-2 & 92 & - & + \\
\hline
\end{tabular}

* Age at onset of infection.

numerical analysis results of HindIII RDPs of chromosomal DNA pointed to the effectiveness of this technique in seperating GBS strains serotyped on the basis of capsular polysaccharide antigens. At similarity levels $>95 \%$, GBS strains with heterogeneous polysaccharide antigens were not linked; although strains of serotypes Ia, III, II and V could be subdivided into RDP types, numerical analysis data generally reflected serotyping. However, no correlation was demonstrated between protein antigens and RDP types, in some instances GBS strains sharing the same polysaccharide antigen but with or without protein antigens showed similarities $>95 \%$.

The type-specific capsular polysaccharide of GBS is recognised as an anti-phagocytic factor. ${ }^{21,22}$ It has also been shown that amongst serotype Ia strains high levels of capsular SA correlates with resistance to tetracycline. ${ }^{18}$ In the present study, all GBS strains of RDP types Ia-1 and III-1 had low capsular SA levels and were susceptible to tetracycline; however, amongst other RDP types there was no correlation with SA levels or tetracycline susceptibility. GBS serotype III isolates from infected neonates or infants have been reported to exhibit lag time growth kinetics in FMC 200P medium. ${ }^{19}$ We found all GBS strains with this character were of RDP type III-3.

Systemic GBS infections can be broadly classified into two distinct disease patterns, septicaemia with respiratory tract infection and meningitis without respiratory symptoms. ${ }^{8,23}$ The former typically presents in the first 5 days of life and is normally the result of vertical transmission of the organism from the maternal genital tract. ${ }^{24}$ Epidemiological studies have shown that more than half of strains from meningitis cases belong to serotype III. ${ }^{6,7}$ Such findings suggest that serotype III strains have a high tropism for the meninges or for the central nervous system. Most cases of early-onset septicaemia with respiratory distress are due to serotype Ia strains. ${ }^{8-10}$

In the present study, most GBS isolates from neonates with early-onset septicaemia were of RDP types Ia- 3 and III- 3 . All the RDP type III- 3 strains also exhibited lag time growth in FMC 200P medium. It has been suggested that this phenomenon is characteristic of strains with a high level of cell-wall lipoteichoic acid. ${ }^{19}$ Lipoteichoic acid has been reported to mediate specific adherence to human fetal cells. ${ }^{25,26}$ However, surface-associated proteins may also be important in mediating adherence. ${ }^{27} \mathrm{We}$ did not study directly the relationship between adherence of GBS and RDP type, but the strong association between strains belonging to RDP types Ia- 3 or III- 3 
and early-onset disease is notable. As various RDP types were represented amongst GBS type III isolates from cases of meningitis, the tropism for the meninges suggested for serotype III strains does not appear to be linked to a particular RDP type but to be common to strains of this serotype.

In the study of GBS disease patterns and the characters of causative strains, our epidemiological analysis with HindIII-RDP typing provided some new information. However, to draw firmer conclusions, more GBS strains need to be studied. Southern blot hybridisation patterns of restriction digests

\section{References}

1. Lancefield RC. A serological differentiation of specific types of bovine hemolytic streptococci (group B). J Exp Med 1934; 59: 441-458.

2. Lancefield RC. Two serological types of group B hemolytic streptococci with related, but not identical, type-specific substances. J Exp Med 1938; 67: 25-40.

3. Motlová J, Wagner M, Jelínková J. A search for new group-B streptococcal serotypes. J Med Microbiol 1986; 22: 101105.

4. Pattison IH, Matthews PRJ, Howell DG. The type classification of group-B streptococci, with special reference to bovine strains apparently lacking in type polysaccharide. $J$ Pathol Bacteriol 1955; 69: 51-60.

5. Wilkinson HW, Eagon RG. Type-specific antigens of group B type Ic streptococci. Infect Immun 1971; 4: 596-604.

6. Baker CJ, Barrett FF. Group B streptoccal infections in infants. JAMA 1974; 230: 1158-1160.

7. Parker MT, Stringer J. The pattern of systemic disease due to group-B streptococci. In: Parker MT (ed) Pathogenic streptococci. Chertsey, Reedbooks. 1979: 171-172.

8. Franciosi RA, Knostman JD, Zimmerman RA. Group B streptococcal neonatal and infant infections. $J$ Pediatr $1973 ; 82$ : 707-718.

9. Horn KA, Zimmerman RA, Knostman JD, Meyer WT. Neurological sequelae of group B streptococcal neonatal infection. Pediatrics 1974; 53: 501-504.

10. Oguro H. A study of group B streptococcus with special reference to the relationship between serological type and virulence. J Jap Assoc Infect Dis 1983; 58: 376-384. (Summary in English).

11. Owen RJ. Chromosomal DNA fingerprinting - a new method of species and strain identification applicable to microbial pathogens. J Med Microbiol 1989; 30: 89-99.

12. Takahashi S, Nagano Y. Novel densitometric method for endonuclease analysis of Escherichia coli DNA samples containing multiple plasmids. J Clin Microbiol 1988; 26 : 244-249.

13. Kersters $\mathrm{K}$, De Ley J. Identification and grouping of bacteria by numerical analysis of their electrophoretic protein patterns. J Gen Microbiol 1975; 87 : 333-342.

14. Nagano $Y$, Nagano N, Takahashi S, Suzuki A, Okuwaki $Y$. Sialic acid levels and lag time of growth in chemically defined medium containing $200 \mathrm{mM}$ phosphate among strains of various serotypes of Streptococcus agalactiae. $J$ Clin Microbiol 1989; 27: 2148-2151. obtained with a $16 \mathrm{~S} / 23 \mathrm{~S}$ ribosomal RNA gene probe have been used to identify strains of various bacterial species. ${ }^{11}$ The main advantage of this technique is that it greatly reduces the number of bands in the RDP and so simplifies interpretation. ${ }^{11}$ This technique may allow RDP differences between GBS isolates to be detected and analysed without the need for scanning by laser densitometry.

We thank Mr Y. Ida and Mr T. Maruko of Funabashi Medical Center for their co-operation.

15. Sneath PHA. Numerical taxonomy: the principles and practice of numerical classification. San Francisco, WH Freeman. 1973.

16. Aminoff D. Methods for the quantitative estimation of $N$ acetylneuraminic acid and their application to hydrolysates of sialomucoids. Biochem J 1961 ; 81 : 384-392.

17. Thornsberry C, Anhalt J, Barry AL et al. Methods for dilution antimicrobial susceptibility tests for bacteria that grow aerobically. National Committee for Clinical Laboratory Standards. Villanova, USA. 1983: 3.

18. Nagano $Y$, Nagano N, Takahashi S, Suzuki A, Okuwaki $Y$. Screening of type Ia and Ib Streptococcus agalactiae strains with high sialic acid levels by determination of susceptibility to tetracyclines. J Clin Microbiol 1989; 27: 2767-2771.

19. Maurer JJ, Mattingly SJ. In vitro method to differentiate isolates of type III Streptococcus agalactiae from symptomatic and asymptomatic patients. J Clin Microbiol 1988; 26: 686-691

20. Terleckyj B, Willett NP, Shockman GD. Growth of several cariogenic strains of oral streptococci in a chemically defined medium. Infect Immun 1975; 11 : 649-655.

21. Yeung MK, Mattingly SJ. Isolation and characterization of type III group B streptococcal mutants defective in biosynthesis of the type-specific antigen. Infect Immun $1983 ; 42$ : 141-151.

22. Yeung MK, Mattingly SJ. Biosynthetic capacity for typespecific antigen synthesis determines the virulence of serotype III strains of group B streptococci. Infect Immun $1984 ; 44: 217-221$.

23. Baker CJ, Barrett FF, Gordon RC, Yow MD. Suppurative meningitis due to streptococci of Lancefield group B: a study of 33 infants. J Pediatr 1973; 82: 724-729.

24. Baker CJ, Barrett FF. Transmission of group B streptococci among parturient women and their neonates. $J$ Pediatr 1973; 83:919-925.

25. Nealon TJ, Mattingly SJ. Role of cellular lipoteichoic acids in mediating adherence of serotype III strains of group B streptococci to human embryonic, fetal, and adult epithelial cells. Infect Immun 1984; 43: 523-530.

26. Nealon TJ, Mattingly SJ. Kinetic and chemical analyses of the biologic significance of lipoteichoic acids in mediating adherence of serotype III group B streptococci. Infect Immun 1985; 50: 107-115.

27. Miyazaki S, Leon O, Panos C. Adherence of Streptococcus agalactiae to synchronously growing human cell monolayers without lipoteichoic acid involvement. Infect Immun 1988; 56: 505-512. 